\title{
Detection of enteroadherent Escherichia coli associated with diarrhoea in Italy
}

\author{
R. MORELLI, L. BALDASSARRI, V. FALBO, G. DONELLI and A. CAPRIOLI* \\ Laboratorio di U/trastrutture, Istituto Superiore di Sanita, Viale Regina Elena, 299-00161 Rome, Italy
}

\begin{abstract}
Summary. One hundred and sixty-eight isolates of Escherichia coli obtained in Italy from 112 children with diarrhoea and 56 age-matched controls were examined by the HEp- 2 cell adhesion assay. Sixteen strains showed localised adherence (LA), 29 showed diffuse adherence (DA) and eight strains showed aggregative adherence (AA). No adhesion pattern was significantly associated with disease. Strains that showed LA or AA were further characterised by serotyping, fluorescent actin staining (FAS) test and hybridisation with the EPEC adherence factor (EAF), E. coli attaching and effacing (eae) and enteroaggregative (EAgg) DNA probes. Strains that showed poor LA were FAS-negative, did not belong to EPEC serotypes and did not hybridise with EPEC probes. Conversely, the two strains that showed a good LA pattern belonged to serotype O128:H2, were FAS positive and hybridised with the eae probe. No isolate hybridised with the EAF probe. Only three of the eight strains with the AA pattern hybridised with the EAgg probe. Probe positivity correlated with the ability to produce clumps at the surface of the liquid culture and to agglutinate rat erythrocytes. In two of these EAgg probe-positive strains, electronmicroscopy revealed the presence of fibrillar bundles which seem to mediate bacterial aggregation.
\end{abstract}

\section{Introduction}

The property of some Escherichia coli strains to adhere to HEp-2 or HeLa cells has been used to identify some categories of $E$. coli associated with diarrhoea. ${ }^{1-3}$ Localised (LA), diffuse (DA) and aggregative (AA) patterns of adherence have been described. Localised adherence has been associated with strains that belong to the characteristic enteropathogenic E. coli serotypes (EPEC).$^{2-4}$ This pattern is characterised by tight clusters of adherent bacteria on the surface of cells. LA-positive $E$. coli strains interact with both the intestinal mucosa and cultured cells, producing either in vivo or in vitro a characteristic cytoskeletal lesion referred to as "attaching and effacing" (A/E). ${ }^{5}$ High concentrations of filamentous actin are seen in the host cell beneath the site of bacterial attachment, a characteristic which has been utilised in the fluorescent-actin staining (FAS) assay to reveal the presence of $\mathrm{A} / \mathrm{E}$ lesions in tissue culture cells. ${ }^{6}$

In some strains, a particular 60-MDa plasmid was shown to be necessary for the full expression of LA. ${ }^{4-7}$

Received 10 March 1994; revised version accepted 27 June 1994.

*Correspondence should be sent to Dr A. Caprioli.
A 1-kb probe, the "EPEC adherence factor" (EAF) probe, has been obtained from this plasmid ${ }^{8}$ and used for epidemiological studies. ${ }^{9-10}$ The pathogenicity of LA-positive strains has been demonstrated in human volunteer studies ${ }^{4}$ and their role in childhood diarrhoea was confirmed in several epidemiological surveys in Asia and South America. ${ }^{2,9-10}$

$E$. coli strains that show DA (DAEC) bind to the entire available surface of cells as well separated, distinct bacteria ${ }^{1}$ and do not belong to particular serotypes. Their pathogenicity and epidemiological significance are still controversial. ${ }^{1,2,11,12}$

The AA pattern is characterised in vitro by clumps of bacteria with a "stacked brick" appearance that are attached to the cell monolayer and to exposed areas of the glass slide. ${ }^{1}$ Recently, fimbrial structures (aggregative adherence fimbriae I, AAF/I) have been involved in this kind of adhesion. ${ }^{13-15}$ Strains that show AA have been termed enteroaggregative $E$. coli (EAggEC). They usually carry a $60-\mathrm{MDa}$ plasmid which confers AA and also encodes bundle-forming fimbriae ${ }^{14}$ and a heat-stable enterotoxin. ${ }^{16}$ A $1-k b$ fragment from this plasmid was found to be a highly specific DNA probe for identifying EAggEC. ${ }^{17}$ Recent epidemiological studies have implicated EAggEC strains as causative agents of persistent diarrhoea in 
infants and young children in South America and India. ${ }^{1,9,18,19}$ The involvement of adherent $E$. coli in childhood diarrhoea has been studied widely in developing countries. ${ }^{2,9-11,20}$ The characteristics of strains that belong to different EPEC serogroups isolated from epidemic outbreaks in the $\mathrm{USA}^{21}$ and sporadic cases in the $\mathrm{UK}^{22-25}$ have been reported, but the incidence and epidemiological features of the infections by the different groups of adherent $E$. coli in developed countries are still unknown.

This study reports the detection of enteroadherent $E$. coli in children with and without diarrhoea in Italy and their characterisation with adhesion-related DNA probes. Strains showing aggregative adhesion were further studied by electronmicroscopy.

\section{Materials and methods}

\section{Study population}

Patients consisted of 112 children, with a mean age of 23.9 (range 1-106) months, and 44 of them were infants $<1$ year old. They were admitted consecutively because of diarrhoea to the paediatric wards of two hospitals in Northern and Central Italy. Cases were observed during 1 year, both as inpatients ( 73 children) and outpatients ( 39 children).

Patients were enrolled in the study irrespective of the duration of diarrhoea or previous antibiotic treatment. Clinical details were ascertained from hospital clinical records and, in the case of outpatients, from questionnaires completed by their parents. Specimens were also collected from 56 children admitted to the same hospitals with other diseases, and without diarrhoea in the previous 2 weeks. One control child was enrolled for every two diarrhoeic patients. The age, sex and seasonal distribution of controls were approximately proportional to those of patients with diarrhoea.

\section{Stool examination}

Stool specimens were collected on admission and examined for common enteric pathogens as described previously. ${ }^{26}$ For $E$. coli isolation, faeces were streaked on to MacConkey agar plates and incubated overnight at $37^{\circ} \mathrm{C}$. Ten lactose fermenting colonies tentatively recognised as $E$. coli were picked from each sample, pooled on to nutrient agar slants and examined by the HEp-2 cell adhesion assay. Positive cultures were streaked on to MacConkey agar and the assay was repeated on each single colony. Strains that adhered to HEp-2 cells were identified by the API 20 E system (Biomérieux, France). E. coli serogrouping was by standard techniques ${ }^{27}$ with rabbit antisera against the following EPEC serogroups: O26, O55, O86, O111, O114, O119, O124, O125, O126, O127, O128 and O142. Further serotyping was performed at the International E. coli and Klebsiella Centre, Statens Seruminstitutet, Copenhagen, Denmark.

\section{HEp-2 adhesion assay}

The adherence patterns were assessed as described by Nataro et al. ${ }^{1}$ with $\mathrm{HEp}-2$ monolayers grown on glass coverslips. An overnight broth culture of bacteria $\left(2 \times 10^{8} \mathrm{cfu}\right)$ was added to the cell monolayer in the presence of D-mannose $1 \% \mathrm{w} / \mathrm{v}$. After incubation for $3 \mathrm{~h}$ at $37^{\circ} \mathrm{C}$ with $\mathrm{CO}_{2} 5 \%$, the monolayer was washed with phosphate buffered saline (PBS) to remove nonadherent bacteria; fresh tissue culture medium was added, and the cells were re-incubated for $3 \mathrm{~h}$ to improve the detection of adhesion patterns. LA was quantified according to the method of Knutton and co-workers ${ }^{24}$ by counting 500 cells on randomised microscopic fields, and recording the percentage of cells with adherent microcolonies. LA was defined as good when the percentage of cells with microcolonies was $>50 \%$, and poor when the microcolonies were very small and the percentage was $<50 \%$. The FAS test was performed according to Knutton et al. ${ }^{6}$ Positive controls of EPEC $\left(\mathrm{LA}^{+}, \mathrm{FAS}^{+}\right), \mathrm{EAggEC}$ and DAEC were included in each experiment.

\section{Test for verotoxin $(V T)$ production}

Sterile culture supernates of the bacterial strains grown in trypticase soy broth (TSB) were tested for the presence of VT by the Vero cell cytotoxicity assay as described previously. ${ }^{28}$

\section{Bacterial clump formation and haemagglutination assay}

EAggEC strains were grown in LB medium in static culture at $37^{\circ} \mathrm{C}$ overnight and the formation of bacterial clumps at the surface of the medium was judged with the naked eye. ${ }^{29}$

The same cultures were tested for agglutination of rat erythrocytes in the presence of D-mannose $0.5 \%{ }^{23}$

\section{Transmission electronmicroscopy (TEM)}

EAggEC isolates were observed by negative staining for the production of fimbriae. Bacterial cells, grown in LB medium, were washed and resuspended three times in distilled water. A drop of suspension was applied to a carbon-coated EM grid (400 mesh), and then stained with sodium-phosphotungstate (NaPT) $1 \%$. The samples were examined in a Zeiss 902 electronmicroscope.

\section{Scanning electronmicroscopy (SEM)}

Infected HEp-2 cell monolayers were fixed in glutaraldehyde $3 \%$ in cacodylate buffer $(0 \cdot 1 \mathrm{M} ; \mathrm{pH} 7 \cdot 0)$ overnight at $4^{\circ} \mathrm{C}$, washed twice in the same buffer and post-fixed in osmium tetroxide $1 \%$ for $1 \mathrm{~h}$. The samples were dehydrated in ethanol before critical point drying and sputter coating with gold (thickness c. $20 \mathrm{~nm}$ ) and then observed with a Cambridge 360 electronmicroscope. 


\section{DNA hybridisation tests}

Broth cultures of the strains were spotted on LA agar plates and incubated overnight at $37^{\circ} \mathrm{C}$. Probepositive and -negative strains were included as controls on each plate. Colonies were replicated on to Hybond$\mathrm{N}$ nylon membranes and treated for the colony hybridisation test. ${ }^{30}$

The EAF, ${ }^{8} E$. coli attaching and effacing $(e a e),{ }^{31}$ enteroaggregative (EAgg), ${ }^{17}$ and diffuse adherence ${ }^{9}$ probes were kindly provided by $\operatorname{Dr} \mathrm{M}$. M. Levine, University of Maryland, Baltimore, MD, USA. Fragments were separated by gel electrophoresis, extracted from low-melting-point agarose and labelled with digoxigenin-dUTP (non-radioactive DNA labelling and detection kit; Boehringer Mannheim, Germany). DNA hybridisation was performed according to the manufacturer's instructions.

\section{Results}

Neither the colony pools nor the isolated strains produced VT. The prevalence of adherent $E$. coli strains among patients and controls, as identified by the HEp-2 cell assay, is shown in table I. No statistically significant association between diarrhoea and the adhesive properties of isolated $E$. coli was demonstrated. In particular, DAEC and poor LA strains were frequently found in the control group.

Table I. Prevalence of $E$. coli strains with different adhesion pattern in the stools of 112 children with diarrhoea and 56 controls

\begin{tabular}{lclc} 
Pattern of adherence & \multicolumn{3}{c}{$\begin{array}{c}\text { Number (\%) of strains } \\
\text { isolated from }\end{array}$} \\
\cline { 2 - 4 } & cases & controls & $\mathrm{p} \dagger$ \\
\hline Localised (good) & $2(1 \cdot 8)$ & 0 & $0 \cdot 45$ \\
Localised (poor) & $10(8 \cdot 9)$ & $4(7 \cdot 2)$ & $0 \cdot 48$ \\
Diffuse & $22(19 \cdot 6)$ & $7(12 \cdot 5)$ & 0.39 \\
Aggregative & $7(6 \cdot 25)$ & $1(1 \cdot 8)$ & $0 \cdot 20$ \\
\hline
\end{tabular}

*See Materials and methods.

$\nmid$ Fisher's exact test.
Strains that showed the LA or AA pattern were further characterised as described earlier.

\section{Strains that showed LA}

All strains that showed poor LA in the HEp-2 cell assay were FAS-negative and did not hybridise with EPEC probes. Two of these strains, isolated from diarrhoeic cases, belonged to EPEC serogroups; however, their serotypes (O127:H21 and O111:H8) were not characteristic of EPEC strains.

Both strains with good LA $(60 \%$ of cells with microcolonies) belonged to the EPEC serotype O128: H2, were FAS-positive and hybridised with the eae probe but not with the EAF probe. The children from whom these EPEC strains were isolated were aged 20 and 47 months, and the youngest had a concomitant infection with rotavirus.

\section{Strains that showed AA}

The characteristics of EAggEC are shown in table II; none of the strains was FAS positive and only two belonged to EPEC serogroups (O55, O86). Two isolates from diarrhoeic cases and one from a control hybridised with the EAgg probe. The probe-positive strains were isolated from a 26-month-old child who had diarrhoea for $>10$ days, and from a 3-month-old infant with bloody diarrhoea that lasted 4 days. No other enteropathogen was identified in the stools of these two patients. Three of the five patients from whom AA-positive EAgg probe-negative strains were isolated, had a concomitant infection with salmonella (one case) or cryptosporidium (two cases).

Only the probe-positive strains produced clumps at the surface of the liquid culture and agglutinated rat erythrocytes in the presence of D-mannose $0.5 \%$. Two different kinds of fimbrial structures were observed when negatively stained, AA strains were examined by electronmicroscopy (figure a, b): 5-nm-diameter rodlike fimbriae were observed in four strains, and fibrillar bundles that resembled those previously described in EAggEC ${ }^{13-15}$ in two strains (table II). The diameter of the bundles ranged from $20 \mathrm{~nm}$ to $60 \mathrm{~nm}$ depending on

Table II. Characteristics of enteroaggregative $E$. coli strains

\begin{tabular}{|c|c|c|c|c|c|c|c|c|}
\hline \multirow{2}{*}{$\begin{array}{l}\text { Strain } \\
\text { no. }\end{array}$} & \multicolumn{4}{|c|}{ Hybridisation with probe } & \multirow{2}{*}{ Serotype } & \multirow{2}{*}{$\begin{array}{l}\text { Clump } \\
\text { formation }\end{array}$} & \multirow{2}{*}{$\begin{array}{l}\text { Mannose-resistant } \\
\text { haemagglutination }\end{array}$} & \multirow{2}{*}{$\begin{array}{c}\text { Fimbrial } \\
\text { type* }\end{array}$} \\
\hline & $\begin{array}{l}\text { EPEC adherence } \\
\text { factor }\end{array}$ & enteroaggregative & eae & $\begin{array}{l}\text { diffuse } \\
\text { adherence }\end{array}$ & & & & \\
\hline E-F 36 & - & - & - & - & $\mathrm{O} 55: \mathrm{H} 45$ & - & - & $\mathbf{R}$ \\
\hline E-F 37 & - & - & - & - & $\mathrm{O} 10: \mathrm{H} 4$ & - & - & - \\
\hline E-F 40 & - & + & - & - & $\mathrm{O} 78,87,92: \mathrm{H} 33$ & + & + & $\mathrm{R}, \mathrm{FB}$ \\
\hline E-F 4l & - & + & - & - & $\mathrm{O} 77: \mathrm{H} 1$ & + & + & $\mathbf{R}$ \\
\hline E-F 42 & - & - & - & - & $\mathrm{O} 1: \mathrm{H} 4$ & - & - & - \\
\hline E-F 43 & - & - & - & - & $\mathrm{O} ?: \mathrm{H} 4$ & - & - & - \\
\hline E-F 45 & - & - & - & - & $\mathrm{O} 11: \mathrm{H} 4$ & - & - & - \\
\hline E-F $46 \dagger$ & - & + & - & - & $\mathrm{O} 86: \mathrm{H} 2$ & + & + & $\mathrm{R}, \mathrm{FB}$ \\
\hline
\end{tabular}

*Fimbrial type assessed by electronmicroscopy: R, rod; FB, fibrillar bundle.

$\dagger$ Strain from an asymptomatic control. 


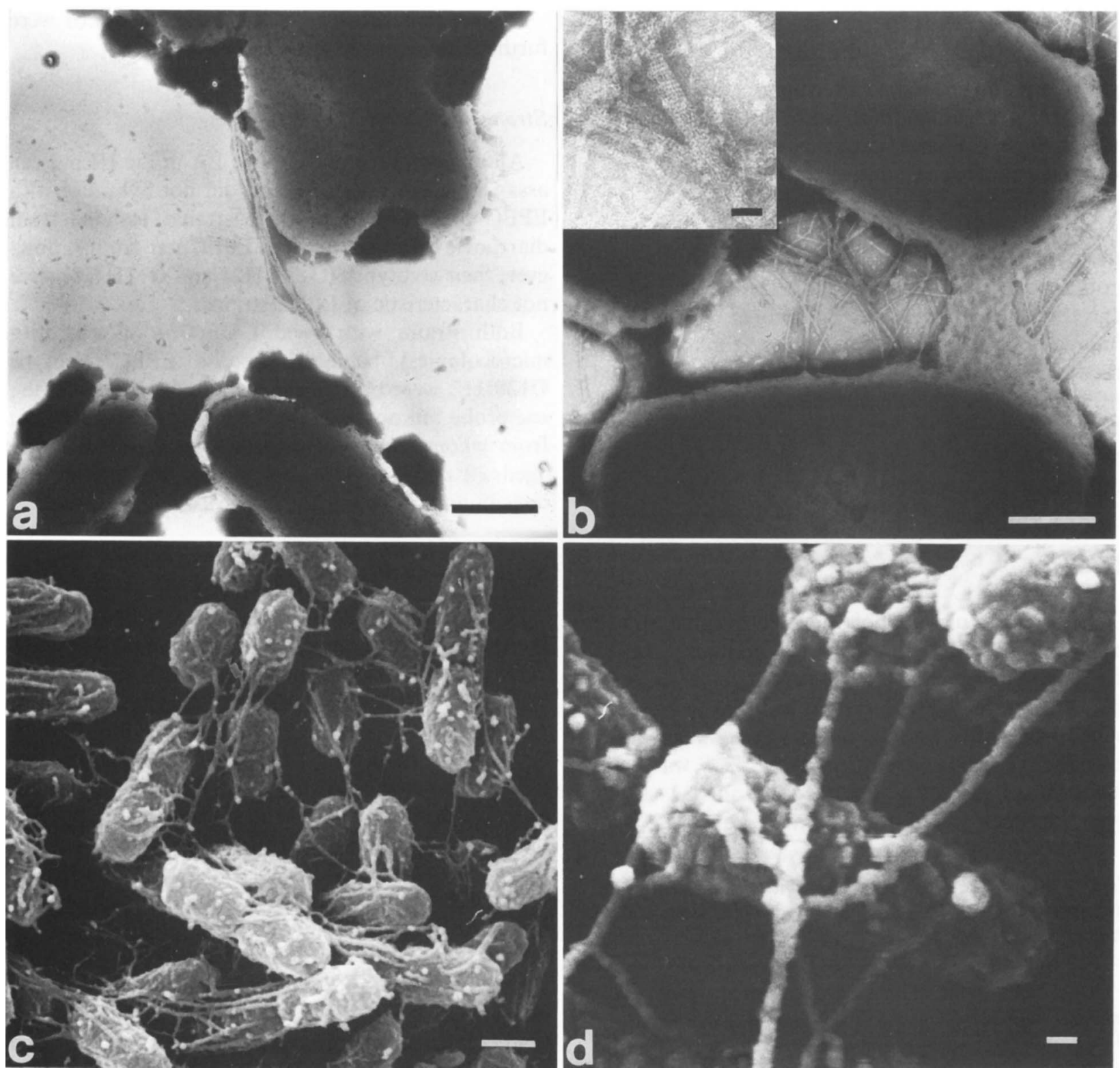

Figure. Electronmicrographs showing the two distinct type of fimbriae produced by the EAggEC strains. a, One or a small number of fibrillar bundles were produced by EAgg probe-positive strains $(\mathrm{bar}=0.5 \mu \mathrm{m}) ; \mathbf{b}$, A typical bundle is seen extending between bacteria; rod-like fimbriae are also present. At high magnification (inset; bar $=25 \mathrm{~nm}$ ), a regularly repeating periodicity was observed along the length of the fibrillar bundle ( $\mathrm{bar}=250 \mathrm{~nm}$ ). $\mathbf{c}$, At the scanning electronmicroscopy analysis, a filamentous network is seen forming EAggEC colonies $(\mathrm{bar}=0.5 \mu \mathrm{m}) ; \mathbf{d}$, filaments seem to connect bacteria together $(\mathrm{bar}=125 \mathrm{~nm})$.

the number of single filaments involved (figure a). In agreement with Knutton et $_{\text {al. }}{ }^{13}$ a repeating periodicity of $c .5 \mathrm{~nm}$ was observed along the fibrillar bundles (figure $b$, inset).

When observed by SEM (figure c, d), the two strains positive for the fibrillar bundles showed the presence of a filamentous network that appeared to connect bacteria together and to the glass coverslip. Considering the gold layer thickness, the diameter of such filaments was consistent with that of the fibrillar bundles observed by TEM.

\section{Discussion}

The involvement of tissue culture adherent $E$. coli in childhood diarrhoea has been well established in several case-control studies in developing countries.
EPEC strains showing strong LA and carrying the EAF gene have been found to be an important cause of diarrhoea in Mexico, ${ }^{2}$ Brazil $^{10}$ and Chile. ${ }^{9}$ EAggEC strains have been associated with persistent diarrhoea in Mexico and India. ${ }^{1,2,9.19}$ Conversely, diffuse adhering strains have often been isolated with similar frequencies from patients with diarrhoea and from non-diarrhoeal controls. ${ }^{1,2,19}$

In this study, strains showing DA or poor LA were found frequently among cases and controls. On the other hand, strains with good LA or AA also appeared not to be associated with disease, although the small numbers examined are inconclusive. The two characteristic EPEC strains isolated in this investigation belonged to serotype $\mathrm{O} 128: \mathrm{H} 2$. As in recent studies in the UK, ${ }^{22,25}$ they were FAS positive and hybridised with the eae probe, but not with the EAF probe. 
The HEp-2 assay revealed several strains that showed poor LA, but none of them exhibited any of the features considered to be related to the ability to cause diarrhoea, namely positivity in the FAS test, hybridisation with the eae probe and typical EPEC serotype. These results suggest the opportunity to confirm, for strains from industrialised countries, the results of the HEp-2 cell assay with the FAS test or by hybridisation with the eae probe, or both.

The EAgg probe recognised only three of these strains and, interestingly, only the probe-positive isolates showed characteristics reported for EAggEC in other studies, ${ }^{13,23,29}$ such as bacterial clump formation, haemagglutination and belonging to particular serogroups. In particular, one of the strains, which was judged by the Escherichia Centre in Copenhagen to possess a complex serotype (O78, O92, O87:H33), is likely to be similar to strain 221 , previously considered to be of serotype $\mathrm{O} 78: \mathrm{H} 33,{ }^{32}$ and then assigned to serogroup $\mathrm{O} 92$ by Scotland et al ${ }^{23}$ As reported in other studies, ${ }^{17,18,23}$ strains with the aggregative phenotype did not hybridise with the EAgg probe. The

\section{References}

1. Nataro JP, Kaper JB, Robins-Browne R, Prado V, Vial PA, Levine MM. Patterns of adherence of diarrheagenic Escherichia coli to HEp-2 cells. Pediatr Infect Dis J 1987; 6: 829-831.

2. Cravioto A, Tello A, Navarro A et al. Association of Escherichia coli HEp-2 adherence patterns with type and duration of diarrhoea. Lancet 1991; 337: 262-264.

3. Mathewson JJ, Johnson PC, DuPont HL et al. A newly recognized cause of travelers diarrhea: enteroadherent Escherichia coli. J Infect Dis 1985; 151: 471-475.

4. Levine MM, Nataro JP, Karch $\mathrm{H}$ et al. The diarrheal response of humans to some classic serotypes of enteropathogenic Escherichia coli is dependent on a plasmid encoding an enteroadhesiveness factor. $J$ Infect Dis 1985; 152: 550-559.

5. Moon HW, Whipp SC, Argenzio RA, Levine MM, Giannella RA. Attaching and effacing activities of rabbit and human enteropathogenic Escherichia coli in pig and rabbit intestines. Infect Immun 1983; 41: 1340-1351.

6. Knutton S, Baldwin T, Williams PH, McNeish AS. Actin accumulation at sites of bacterial adhesion to tissue culture cells: basis of a new diagnostic test for enteropathogenic and enterohemorrhagic Escherichia coli. Infect Immun 1989; 57: 1290-1298.

7. Baldini MM, Kaper JB, Levine MM, Candy DCA, Moon HW Plasmid-mediated adhesion in enteropathogenic Escherichia coli. J Pediatr Gastroenterol Nutr 1983; 2: 534-538.

8. Nataro JP, Baldini MM, Kaper JB, Black RE, Bravo N, Levine MM. Detection of an adherence factor enteropathogenic Escherichia coli with a DNA probe. J Infect Dis $1985 ; 152$ : 560-565.

9. Levine MM, Prado V, Robins-Browne R et al. Use of DNA probes and HEp-2 cell adherence assay to detect diarrheagenic Escherichia coli. J Infect Dis 1988; 158: 224-228.

10. Gomes TA, Rassi V, MacDonald KL et al. Enteropathogens associated with acute diarrheal disease in urban infants in San Paolo, Brazil. J Infect Dis 1991; 164: 331-337.

11. Giron JA, Jones T, Millan-Velasco F et al. Diffuse-adhering Escherichia coli (DAEC) as a putative cause of diarrhea in Mayan children in Mexico. J Infect Dis 1991; 163: 507-513.

12. Tacket CO, Moseley SL, Kay B, Losonsky G, Levine MM. Challenge studies in volunteers using Escherichia coli strains with diffuse adherence to HEp-2 cells. $J$ Infect Dis $1990 ; 162: 550-552$

13. Knutton S, Shaw RK, Bhan MK et al. Ability of Enteroaggregative Escherichia coli strains to adhere in vitro to human mucosa. Infect Immun 1992; 60: 2083-2091.

14. Nataro JP, Yikang D, Maneval DR, German AL, Martin WC, existence of different categories of EAggEC has been proposed ${ }^{17,18}$ however, we cannot exclude the possibility that the probe-negative isolates in this study were strains that showed a strong DA, which is sometimes difficult to distinguish from the Agg pattern. On the other hand, none of these aggregative strains hybridised with the DA probe.

Electronmicroscopy showed fibrillar bundles in two of the probe-positive strains similar to those described by Knutton et al..$^{13}$ and Nataro et al..$^{14}$. These fimbriae appeared to participate in the formation of EAggEC colonies linking bacteria together, as described previously. ${ }^{13,14}$ This hypothesis seems to be supported by SEM observations, that showed a filamentous network responsible for the bacterial aggregation.

Even though the numbers in this group of patients are small, the present study seems to exclude EAEC infections as a major cause of diarrhoea in Italian children.

This work was partially supported by National Research Council (CNR) grant 92.02516.CT04 and Targeted Project "Prevention and Control Disease Factors", grant 93.00769.PF41.

Levine MM. Aggregative adherence fimbriae I of Enteroaggregative Escherichia coli mediate adherence to HEp2 cells and hemagglutination of human erythrocytes. Infect Immun 1992; 60: 2297-2304.

15. Nataro JP, Yikang D, Giron JA, Savarino SJ, Kothary MH, Hall R. Aggregative adherence fimbria I expression in Enteroaggregative Escherichia coli requires two unlinked plasmid regions. Infect Immun 1993; 61 : 1126-1131.

16. Savarino SJ, Fasano A, Robertson DC, Levine MM. Enteroaggregative Escherichia coli elaborate a heat-stable enterotoxin demonstrate in an in vitro rabbit intestinal model. J Clin Invest 1991; 87: 1450-1455.

17. Baudry B, Savarino SJ, Vial P, Kaper JB, Levine MM. A sensitive and specific DNA probe to identify enteroaggregative Escherichia coli, a recently discovered diarrhoeal pathogen. $J$ Infect Dis 1990; 161 : 1249-1251.

18. Vial PA, Robins-Brown R, Lior $\mathrm{H}$ et al. Characterization of enteroadherent-aggregative Escherichia coli, a putative agent of diarrheal disease. J Infect Dis 1988; 158: 70-79.

19. Bhan MK, Ray P, Levine MM et al. Enteroaggregative Escherichia coli associated with persistent diarrhea in a cohort of rural children in India. J Infect Dis 1989; 159: 1061-1064

20. Echeverria $P$, Serichantalerg $O$, Changchawalit $S$ et al. Tissue culture-adherent Escherichia coli in infantile diarrhea. $J$ Infect Dis 1992; 165: 141-143.

21. Moyenuddin M, Wachsmuth KI, Moseley, SL, Bopp CA, Blake PA. Serotype, antimicrobial resistance, and adherence properties of Escherichia coli strains associated with outbreaks of diarrhea illness in children in the United States. J Clin Microbiol 1989; 27: 2234-2239.

22. Smith HR, Scotland SM, Stokes N, Rowe B. Examination of strains belonging to enteropathogenic Escherichia coli serogroups for genes encoding EPEC adherence factor and Vero cytotoxins. J Med Microbiol 1990; 31 : 235-240.

23. Scotland SM, Smith HR, Said B, Willshaw GA, Cheasty T, Rowe B. Identification of enteropathogenic Escherichia coli isolated in Britain as enteroaggregative or as members of a subclass of attaching-and-effacing $E$. coli not hybridising with the EPEC adherence-factor probe. $J$ Med Microbiol 1991; 35: 278-283.

24. Knutton S, Phillips AD, Smith HR et al. Screening for enteropathogenic Escherichia coli in infants with diarrhea by the fluorescent-actin staining test. Infect Immun 1991; 59: $365-371$.

25. Scotland SM, Smith HR, Rowe B. Escherichia coli O128 strains from infants with diarrhea commonly show localized adhesion and positivity in the fluorescent-actin staining test 
but do not hybridize with an enteropathogenic $E$. coli adherence factor probe. Infect Immun 1991; 59: 1569-1571.

26. Capano G, Guandalini S, Guarino A et al. Enteric infections, cow's milk intolerance and parenteral infections in 118 consecutive cases of acute diarrhoea in children. Eur $J$ Pediatr 1984; 142: 281-285.

27. Ewing WH. Edwards and Ewing's Identification of Enterobacteriaceae, 4th edn. New York, Elsevier Science Publishing Co., Inc. 1986.

28. Caprioli A, Luzzi I, Rosmini $\mathrm{F}$ et al. Hemolytic-Uremic Syndrome and vero cytotoxin-producing Escherichia coli infection in Italy. J Infect Dis 1992; 166: 154-158.

29. Yamamoto T, Endo S, Yokota T, Echeverria P. Characteristics of adherence of Enteroaggregative Escherichia coli to human and animal mucosa. Infect Immun 1991; 59: 3722-3739.

30. Maniatis T, Fritsch EF, Sambrook J. Molecular cloning: a laboratory manual. Cold Spring Harbor, NY, Cold Spring Harbor Laboratory. 1982: 312.

31. Jerse AE, Yu J, Tall BD, Kaper JB. A genetic locus of enteropathogenic Escherichia coli necessary for the production of attaching and effacing lesions on tissue culture cells. Proc Natl Acad Sci USA 1990; 87: 7839-7843.

32. Mathewson JJ, Johnson PC, DuPont HL, Satterwhite TK, Winsor DK. Pathogenicity of enteroadherent Escherichia coli in adult volunteer. J Infect Dis 1986; 154: 524-527. 